胸部・腹部大動脈血行再建術における

\title{
ゼラチン処理人工血管の臨床使用経験
}

\begin{tabular}{|c|c|c|c|c|c|c|c|c|c|c|c|c|c|}
\hline 波 & & 誠 & 饗 & 場 & 正 & 宏 & 成 & 澤 & 隆 & 数 & 馬 & & 博 \\
\hline 田 中 & 弘 & 之 & 村 & 上 & 厚 & 文 & 山 & 田 & 眞 & 高 & 場 & 利 & \\
\hline & & & 堀 & & 豪 & 一* & 山 & 本 & 登** & & & & \\
\hline
\end{tabular}

39 症例の胸部・腹部大動脈血行再建術に Gelseal knitted Dacron graft を臨床応用しその有用性に ついて検討した。胸部大動脈瘤 (TAA) 10 例, 腹部大動脈瘤 (AAA) 19 例, 腸骨動脈領域疾患 (IAL) 10 例に Gelseal graft 直管 16 本, Y graft 23 本を用い血行再建術を施行した。人工血管壁の針通過, 吻合面の密着, 縦方向の伸展性などは良好で人工血管壁の漏血はみられなかった。 さらに従来から用 いていた knitted Dacron (Intervascular MICRON ${ }^{\circledR}$ )と Gelseal graft を非破裂性腹部大動脈瘤症 例にて比較検討した。 その結果, 出血量, 他家血輸血量, 血液生化学的検査, 血液凝固系検査で両群 間に有意の变化は認められなかった。 以上より従来の knitted Dacron graft と比較し, 手術手技的 に良好な吻合操作性を有し, preclotting が不必要であり, 十分な抗漏血性を持ち, 臨床に十分使用で きる優れた人工血管であることが示唆された。 日心外会誌 24 巻 2 号 : 95-100(1995)

Keywords : ゼラチン処理人工血管, 胸部・腹部大動脈血行再建術, preclotting, 代用血管

\section{Clinical Experience with a Gelatin Sealed Dacron Prosthesis}

Makoto Funami, Masahiro Aiba, Takashi Narisawa, Hiroshi Kazuma, Hiroyuki Tanaka, Atsubumi Murakami, Makoto Yamada, Toshihiro Takaba, Gouichi Hori* and Noboru Yamamoto** (Department of Surgery, Showa University School of Medicine, Tokyo, Japan and Department of Thoracic and Cardiovascular Surgery, Fujigaoka Hospital Showa University*, Yokohama, Japan and Kikuna Memorial Hospital**, Yokohama, Japan)

A gelatin-sealed knitted Dacron graft which has zero-porosity at implantation and does not require preclotting preparation has been developed. Gelatin-sealed aortic grafts were implanted into 39 patients and vascular surgery reconstruction was performed for thoracic aortic aneurysm (TAA) in 10, abdominal aortic aneurysm (AAA) in 19, and arteriosclerosis obliterans (ASO) and other conditions in 10. A total of 39 bifurcated or straight grafts were inserted. The Gelseal Dacron graft had superior handling characteristics and biocompatibility in comparison to conventional graft. There was no measurable blood loss from the body of the sealed graft at the time of implantation. The gelatin-sealed Dacron graft $(n=10)$ was compared with an Intervascular Micron ${ }^{\circledR}$ graft $(n=10)$ implanted into the abdominal aorta. No problems were evident with regard to intraoperative bleeding, allogenic and autologous transfusion volume and blood parameters between the two groups. These results suggested that the Gelseal Dacron graft sealed with gelatin was a safe, zero-porosity implantable prosthesis for clinical use. Jpn. J. Cardiovasc. Surg. $24: 95-100(1995)$

Dacron graft は大血管から末梢血管に至る動 脈血行再建術に広く応用されている。大口径人工 血管には woven Dacron が，また中口径人工血管 には knitted Dacron が主に使用されており, 人工 血管が持つおのおのの特性から選択されてきた.

1993 年 8 月 31 日受付, 1994 年 5 月 30 日採用

昭和大学外科 $\bar{\top} 142$ 東京都品川区旗の台 1-5-8

* 昭和大学藤が丘病院心臓血管外科

** 菊名記念病院
人工血管の信頼性については臨床成績から確固た る実績が報告されているものの，救命的な欠点と 考えられる血液漏出については完全に解決されて いない.また preclotting の方法もいまだ確実と はいえない.とくに体外循環などの heparin 使用 下における大動脈置換時の出血制御には問題を残 している.また血液漏出から発生する各種の合併 症は術中から長期予後に関する成績に影響を与え 
ていると考えられる. 今回, 胸部大動脈から腸骨 動脈の血行再建術の臨床応用に gelatin で被覆さ れた zero-porosity の knitted Dacron graft (Gelseal Triaxial $\left.{ }^{\circledR}\right)$ を用い, その術中術後成績を検討 した。さらに AAA 症例については従来から使用 している人工血管と比較検討したので報告する.

\section{対象と方法}

1991 年 8 月から 1992 年 4 月までの 9 か月間に 施行した人工血管置換術 39 症例を対象とした. 疾 患は真性胸部大動脈瘤 2 例（遠位弓部 1 例, 下行 1 例), 胸部大動脈解離 7 例 (Stanford $\mathrm{A}$ 型 1 例, B 型 6 例), Marfan 症候群 1 例, AAA 19 例(破裂 4 例, 非破裂 15 例), 大動脈・腸骨動脈領域の閉 塞性動脈硬化症 (ASO) 8 例, 腸骨動脈瘤 1 例, 医

表 1 Gelseal Dacron graft 手術症例

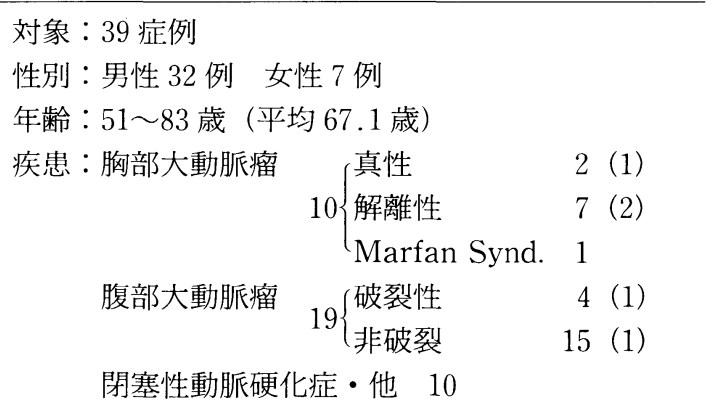

( ) : 死亡例
原性腸骨動脈解離 1 例であった。症例のうち破裂 性 AAAの 4 例に緊急手術を施行した。年齢は 51 歳から 83 歳で平均 67.1 歳であった。性別は男性 32 例，女性 7 例である(表 1 )。

手術術式は全例に人工血管置換術を施行した。 血行再建術に使用したGelseal Triaxial ${ }^{\circledR} は$, VASCUTEK 社製Triaxial に gelatinを被覆し た無孔性 (zero-porosity) 人工血管である。この人 工血管は preclotting 操作が不必要で，血行再建 術直前に生理食塩水に漫水させて使用した. TAA に対して直管 10 本の人工血管を使用し, AAA で は Y 字型人工血管 19 本を, ASO に Y 字型人 工血管 4 本を, その他の疾患には直管 6 本を用い た(表 2 ).

血行再建術の補助手段として TAAの 4 例に全 身 heparin 化を用いた完全体外循環を施行した。 Centrifugal pump を用い, 左房脱血, 大腿動脈送 血法で左心バイパスを行ったものは 6 症例あり, 大動脈遮断直前に全身 heparin 化を heparin 量 $0.5 \mathrm{mg} / \mathrm{kg}$ で行い, その後は ACT 值 200 秒前後 を目標值として heparin を追加投与した。非体外 循環症例の AAA 19 例, ASO 8 例, 他 2 例におい ては初回 heparin 投与は $0.5 \mathrm{mg} / \mathrm{kg}$ で行い, ACT 值 150〜200 秒前後を維持した. 術中出血は JMS 社製の非洗浄式自己血回収装置で回収し,リ ザーバー内の $40 \mu \mathrm{m}$ フィルター通過後, 小型ロー

表 2 血行再建部位における補助手段および使用人工血管の形状

\begin{tabular}{|c|c|c|c|c|c|}
\hline & Method & & Graft & $(\mathrm{mm})$ & \\
\hline \multirow{4}{*}{ TAA } & & & \multirow{4}{*}{ Straight graft } & 30 & 2 \\
\hline & $\mathrm{ECC}$ & 4 & & 26 & 2 \\
\hline & Centrifugal pump & 6 & & 24 & 2 \\
\hline & & & & 20 & 4 \\
\hline \multirow{4}{*}{ AAA } & & \multirow{4}{*}{19} & \multirow{4}{*}{ Y graft } & $20 \times 10$ & 3 \\
\hline & & & & $18 \times 9$ & 9 \\
\hline & & & & $16 \times 8$ & 6 \\
\hline & & & & $14 \times 7$ & 1 \\
\hline \multirow{4}{*}{ IAL } & & \multirow{4}{*}{10} & \multirow{2}{*}{ Straight graft } & 10 & 1 \\
\hline & & & & 8 & 5 \\
\hline & & & \multirow{2}{*}{ Y graft } & $16 \times 8$ & 1 \\
\hline & & & & $14 \times 7$ & 3 \\
\hline
\end{tabular}

TAA：胸部大動脈瘤, AAA：腹部大動脈瘤, IAL：腸骨動脈領域 疾患, ECC : extracorporeal circulation 
ラーポンプを用い体内に返血した. TAAの少数 例では硫酸 protamin 中和後に洗浄式血液回収輸 血装置を併用し同種輸血の削減をさらに試みた (表 2 ).

これらの症例に対して, 人工血管吻合操作上の 問題点, 出血量・輸血量・術後合併症などについ て検討を加えた。また非破裂性 AAA を対象に Gelseal graft 使用の 10 症例 (G 群) と従来使用し ていた gelatin 処理なしの knitted Dacron graft (Intervascular MICRON ${ }^{\circledR}$ : 有孔度 $750 \mathrm{cc} / \mathrm{cm}^{2} /$ min)を用いて施行した AAA 手術 10 例( I 群) と を比較検討した. 検查項目は術前, 術後第 1 日, 3 日，5 日， 1 週，2 週，3 週目における $\mathrm{Ht}$ 值， $\mathrm{Hb}$ 量, 白血球数, 血小板数, フィブリノーゲン值, GOT, GPT, 総ビリルビン值, 血中尿素窒素, 血 清クレアチニン, CRP である. 得られた測定結果 は平均值土標準偏差で示し, 有意差検定には Wilcoxon 法にて行い， $p<0.05$ をもって有意差あり とした.

\section{結果}

\section{1）人工血管使用時の評価}

人工血管の操作性は良好であった. 人工血管壁 厚に関しては従来の knitted Dacron 人工血管と 比較してやや厚く, crimping が強い印象を受ける が縫合針の通過抵抗性はなく，刺入は容易であつ た。壁の柔軟性は woven graft に比較し良好で動 脈壁吻合面の密着なども良く, 吻合直後の血液漏 出にかかわる壁のゆがみなども少ない，吻合部の 針刺入点からの出血はなく, 血管壁からの漏血も
まったくなかったが，ペアン鉗子で把持した部分 から少量の漏血を認めた症例があった。 39 症例 中, ヘパリン量 $3 \mathrm{mg} / \mathrm{kg}$ で体外循環を施行した 4 例と少量の heparin を用いた遠心ポンプによる左 心バイパスは 6 例あるが，いずれも人工血管壁か らの出血は認められず術後の人工血管感染などの 合併症も認められなかった。AA 症例における 術後発熱の発生をみると, 経過中の最高值は $37.6 \sim 38.4^{\circ} \mathrm{C}$ (平均 $37.9^{\circ} \mathrm{C}$ ) であり $37^{\circ} \mathrm{C}$ 以上が 3 日以内で推移した症例が $90 \%$ で異常な発熱と考 えられる例はなかった. 手術死亡は 5 例あるが全 例原疾患の病態に関連したもので, 人工血管に起 因するものはなかった。現在術後 16〜24 か月 (19土4 か月)の経過であるが生存 34 例全症例と も人工血管の閉塞や吻合部の狭窄，閉塞所見，拡 張所見などは認めていない. また術後の血行再建 部末梢側の下肢動脈における急性動脈塞栓, 血栓 症の発生や, ASO の症状の増悪などを招来した症 例はない。

2）疾患部位別による出血関連因子

TAA, AAA, IAL のそれぞれの群における出血 関連因子を表 3 に示した. TAA 群の出血量, 輸血 量をみると体外循環使用症例は遠心ポンプ使用症 例に比較して,いずれも多い. AAA 症例では他家 血輸血は平均 $510 \mathrm{ml}$ と少なく, 無輸血手術例は 6 例(32\%)であった(表 3 ).

3）腹部大動脈瘤手術症例における $\mathrm{G}$ 群と I 群の比較

a）術中出血量, 同種血輸血量, $\mathrm{ACT}$ 最大值術 中出血量は $\mathrm{G}$ 群, I 群はそれぞれ $958 \pm 792 \mathrm{ml}$,

表 3 胸部大動脈瘤, 腹部大動脈瘤, 腸骨動脈領域疾患のそれぞれの群 における ACT 最大値, 術中出血量, 他家血輸血量

\begin{tabular}{lcccl}
\hline & & ACT $_{\max }$ & Blood loss & AL $\cdot \mathrm{B} \cdot \mathrm{T}$ \\
\hline TAA & 4 & $1,028 \pm 560$ & $1,390 \pm 883$ & $3,415 \pm 2,180$ \\
ECC & 6 & $271 \pm 19$ & $1,029 \pm 672$ & $1,963 \pm 769$ \\
Centrifugal pump & 19 & $255 \pm 94$ & $1,044 \pm 698$ & $510 \pm 670$ \\
\hline AAA & 10 & $211 \pm 22$ & $304 \pm 231$ & $106 \pm 224$ \\
\hline IAL &
\end{tabular}

TAA：胸部大動脈瘤, AAA：腹部大動脈瘤, IAL：腸骨動脈領域疾 患, $A L \cdot B \cdot T$ : allogenic blood transfusion, ECC : extracorporeal circulation, ACT : activated coagulation time. 
$897 \pm 531 \mathrm{ml}$ ，同種血輸血量は $333 \pm 320 \mathrm{ml}, 367$ $\pm 429 \mathrm{ml}$ で有意差はなかった. ACT 最大值は $\mathrm{G}$ 群で $235 \pm 20$ 秒, I 群で $206 \pm 12$ 秒を示し他の因 子同様に有意差はなかった。両群ともおのおの, 無輸血例は 4 例ずつであった。

\section{b）術中術後の検査値の推移}

$\mathrm{Ht}$ 值では $\mathrm{G}$ 群，I 群は術前值 $40 \pm 2.3 \%, 36.5$ $\pm 3.5 \%$ から術後 3 日目には $33.7 \pm 4.3 \%, 31.3$ 土4.0\%に減少したが 3 週後には $36.8 \pm 4.3 \%, 34.0$ 土4.4\%に復した。 $\mathrm{Hb}$ 量では $\mathrm{G}$ 群，I 群は術前値 $13.4 \pm 1.0 \mathrm{~g} / \mathrm{dl}, 12.0 \pm 1.0 \mathrm{~g} / \mathrm{dl}$ から術後 3 日目に は $11.2 \pm 1.6 \mathrm{~g} / \mathrm{dl}, 10.4 \pm 1.3 \mathrm{~g} / \mathrm{dl}$ の最低值を示し た。両群間に有意差は認めなかった(図 1 )。白血

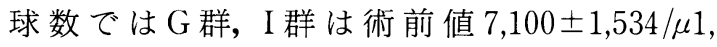
$7,230 \pm 1,052 / \mu 1$ から両群とも術後 1 日目に 12,080 $\pm 5,230 / \mu 1,13,690 \pm 5,768 / \mu 1$ と最高值となり $\mathrm{G}$ 群は 5 日目に $7,410 \pm 2,112 / \mu 1$ へ，I群は 2 週目に $7,970 \pm 2,051 / \mu 1$ に下降したが全経過中，両群間に 有意差は認めなかつた (図 2 ). CRP 值では G 群, I 群は術前値 $0.3 \pm 0.4,0.6 \pm 0.9$ から術後 3 日目に は $15.6 \pm 13.3,21.0 \pm 15.0$ に上昇し以後漸減し 21 日目に術前值に復した。両群間に有意差は認めな かった(図 3 ). 血小板数では $\mathrm{G}$ 群，I 群は術前値 $25.0 \times 10^{4} \pm 7.2 \times 10^{4} / \mu 1,22.5 \times 10^{4} \pm 5.3 \times 10^{4} / \mu 1$ 少 ら G 群は 3 日目に最低值 $12.7 \times 10^{4} \pm 6.8 \times 10^{4} / \mu 1$ へ，I 群は 1 日目に最低值 $13.5 \times 10^{4} \pm 4.3 \times 10^{4} / \mu 1$ となった.しかし両群とも 7 日目には前值に復し，

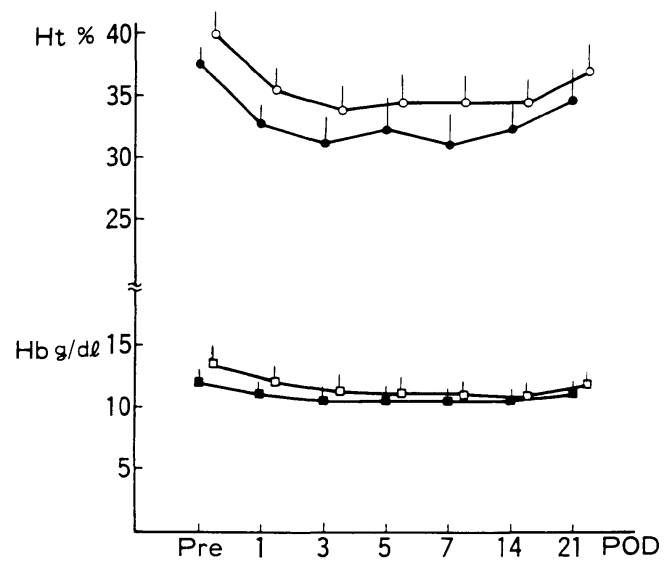

図 1 I 群と $\mathrm{G}$ 群における $\mathrm{Ht}$ 值, $\mathrm{Hb}$ 量の術前後の推 移

: G group, O : I group
14 日目には G 群は前値の $150 \%$ ，I群は $205 \%$ へ上昇し以後は漸減した。両群間に有意差は認め なかった (図 4 ). フィブリノーゲンでは $\mathrm{G}$ 群, I 群 は術前值 $326 \pm 95 \mathrm{mg} / \mathrm{dl}, 310 \pm 63 \mathrm{mg} / \mathrm{dl}$ で $\mathrm{G}$ 群 は 5 日目に最高值 $581 \mathrm{mg} / \mathrm{dl}$ へ，I群は 3 日目に $469 \mathrm{mg} / \mathrm{dl}$ を示した。両群間に有意差は認めなか った(図 5 ).血清総ビリルビン值では $\mathrm{G}$ 群, I 群は 術前值 $0.98 \pm 0.6 \mathrm{mg} / \mathrm{dl}, 0.87 \pm 0.28 \mathrm{mg} / \mathrm{dl}$ で $\mathrm{G}$ 群は 1 日目に最高値 $1.5 \pm 0.7 \mathrm{mg} / \mathrm{dl}$ へ，I 群は 5 日目に $1.36 \pm 0.43 \mathrm{mg} / \mathrm{dl}$ へ上昇後漸減した. 両群 間に有意差は認めなかった. BUN 值では G 群, I

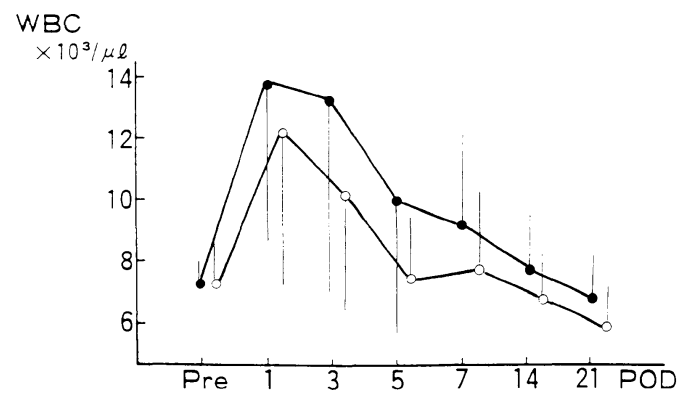

図 2 I 群と G 群における白血球数の術前後の推移 $\bigcirc:$ Group, $:$ I group

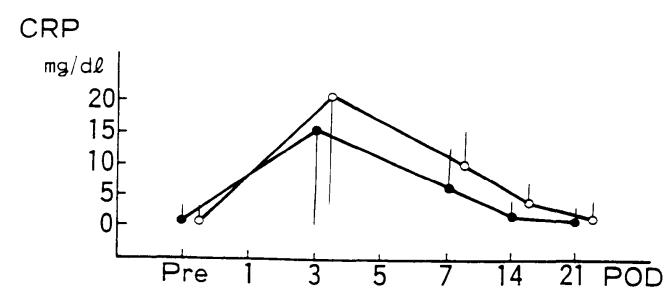

図 3 I 群と $\mathrm{G}$ 群における CRP の術前後の推移 $\bigcirc:$ G group, $:$ I group

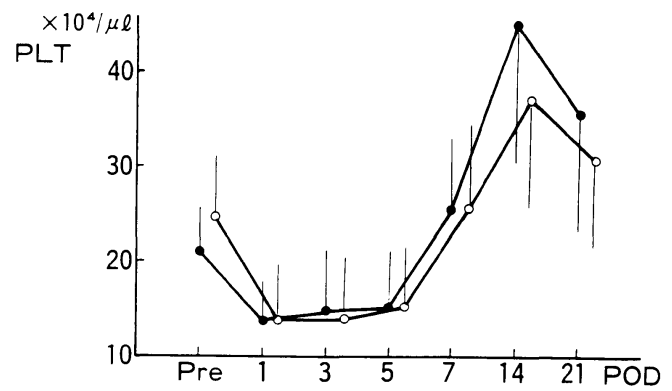

図 4 I 群と G 群における血小板数の術前後の推移 $\bigcirc:$ G group, $\bigcirc$ I group 


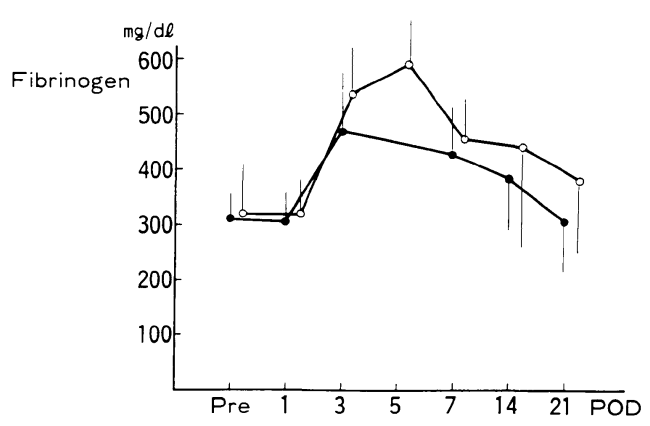

図 5 I 群とG 群における fibrinogen の術前後の推移 $\bigcirc:$ G group, I group

群は術後 5 日目に22.6土18 mg/dl, $22.1 \pm 14.0$ $\mathrm{mg} / \mathrm{dl}$ に上昇し以後漸減した。両群間に有意差は 認めなかった。血清クレアチニン值は両群とも 1 日目に最高值 $1.4 \pm 0.5 \mathrm{mg} / \mathrm{dl}$ となり以後漸減し た。両群間に有意差は認めなかった。 GOT, GPT 值は 2 週目に G 群で $58 \pm 92 \mathrm{IU} / l, 76 \pm 81 \mathrm{IU} / l$, I 群は $16.8 \pm 8.5 \mathrm{IU} / l, 19.1 \pm 10.4 \mathrm{IU} / l$ と有意差 $(p$ <0.05)を認めた。

\section{考察}

Dacron graft は線維の編織形式代用血管とし て血行再建術の基本的条件を満足する材料として 認識されている.Woven 構造の人工血管は低有孔 性であり，経年変化に対する耐久性，機械的強度， 漏血の減少化などの安全性においては改善されて いる ${ }^{1,2)}$. しかし平織りのため人工血管移植初期の 新生内膜形成が不良, 線維間への組織の入込みが 不十分などの特質を有している。一方, knitted Dacron に代表される中有孔性人工血管は新生内 膜形成の安定化が良好で迅速であるなど生体適合 性は優れ, 縫合手技上の操作性も良好であるが, 血管壁からの漏血が多い欠点を有する．今回の症 例でも，その操作性は問題なく ${ }^{3)}$, リークテストで の人工血管からの漏れはほとんどみられなかっ た。

手術では血液漏出を防止するため, preclotting 操作が必要となる.この際, 問題となる点は人工 血管が污染される危険性の増大, 個体差から招来 される不完全な preclotting 効果, 長時間体外循 環使用時などの術中 heparin 化血との長期接触に
よる出血の増大, preclotting 操作に要する手術時 間の延長, 術後の血栓溶解剂使用が制限されるな ど多くの検討すべき要素が残されている。これら の問題点を回避すべく, collagen や albumin, gelatin などであらかじめ人工血管を被覆する方法 が開発され ${ }^{4-8)}$, 各種人工血管が本邦でも多数臨床 使用されている . 今回の使用経験では heparin 化体外循環下においても血管壁からの漏血はまっ たくなく,針刺入点などからの漏血も少なかった。

ヨーロッパ各国および本邦でも Gelseal Dacron graft を用いた多数の血行再建術が報告され つつある10〜12). Gelseal Dacron graft は三軸構造 を有する有孔度 $750 \mathrm{ml} / \mathrm{cm}^{2} / \mathrm{min}$ の knitted Dacronにウシ gelatin で被覆した zero-porosityの 人工血管である.Gelatin はすでに plasma expan$\operatorname{der}\left(\right.$ Hemaccel $\left.{ }^{\circledR}\right)$ として安全性は認められてい る ${ }^{12)}$. 出血に関しては, 体外循環を使用した症例や 術後の血栓溶解剂の投与例においても血管壁から の出血はないとの報告があり ${ }^{3,11)}$, Drury ら ${ }^{12)}$ は Y 字型人工血管を使用した血行再建術において 100 例中 $74 \%$ が無輸血症例であった良好な成績を 示している.今回の検討からは, AAA 手術におけ る G 群と I 群の比較で両群とも無輸血例は $40 \%$ で差はなく，非洗浄式自己血回収法を用いた影響 は出血・輸血関連因子の分析で差は認められなか つた。これは対象とした 2 種の人工血管に関して は漏血性因子では問題がないことを示しているが 個々の症例をみると, G 群症例で吻合部出血は少 ない印象が得られた。また異種タンパク質の反応 による術後の炎症性反応の変化についても, 動物 実験で体内移植後 5 10 日には gelatin の消失を 認めており，その残留が問題になることは少ない と指摘している ${ }^{13)}$. 光顕・電顕による組織学的所見 では予期された仮性内膜の形成異常などはな

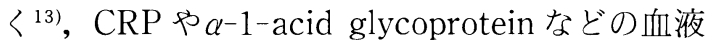
検査でも変化は微量で人工血管周囲の局所の炎症 反応は予想外に少なく，その安全性が報告されて いる ${ }^{14 \sim 16)}$.われわれの $\mathrm{AAA}$ 症例では $37^{\circ} \mathrm{C}$ 微熱 が 3 日程度続いた後は発熱のみられない症例がほ とんどで, 血液検査においては一時的に肝機能障 害を認めた 2 症例があったが特別な炎症反応の六 進を起こした症例はなく本人工血管と発熱の発生 
に関する因果関係は証明されなかった。一方，長 期の開存率についての臨床報告も多く ${ }^{17)}$, Reid $ら^{15)}$ は 100 例の血行再建術における 57 か月の観 察で $99 \%$ の開存を報告している。しかし，これら の報告は腸骨動脈レベルまでの検討が主体であ り，より末梢での開存性については研究段階であ $3^{18)}$. 今回の血行再建例は平均 19 か月と短期間の 観察例であり短期間の開存性については問題がな いと考えるが，より長期的な予後については今後 の検討課題である。また胸部大動脈レベルに本血 管を使用した場合, 拡張性変化, Dacron の劣化が 懸念されるところであるが19)，人工血管の素材と 構造は従来と異なり長期的予後については今後の 問題と考えられる。

\section{結論}

1）Gelseal 人工血管を 39 例の動脈血行再建 術に用いた。

2）人工血管壁からの漏血は認めず，吻合部の 血管壁の密着性は良好で術後の血液凝固系異常は 少なく，早期の感染等も認めなかった。

3）従来の knitted Dacron graft (Intervascular MICRON $\left.{ }^{\circledR}\right)$ と比較し, 手術手技的に良好な 吻合操作性を有し, preclotting が不必要であり, 十分な抗漏血性効果を持っていることから臨床に 十分使用できる優れた人工血管であることが示唆 された。

\section{文献}

1）孟真, 野一色泰晴, 安達隆二ほか: 代用血管 の種類・特色・使用法. 外科治療 47: 504-509, 1992.

2）野一色泰晴：人工血管の病態生理. 医学のあゆみ 134: 682-686, 1985.

3）安達秀雄, 横手祐二, 許 俊鋭ほか：ゼラチン処 理人工血管の臨床応用とその遠隔成績. 人工臟器 20 : 544-549, 1991.

4) Cooley, D. A., Romagnoli, A., Milan, J. D., et al.: A method of preparing woven Dacron aortic grafts to prevent interstitial hemorrhage. Cardiac. Dis. Bull. Tex. Heart Inst. 8 : 48-52, 1981.

5) Jonas, R. A., Ziemer, G., Schoen F. J., et al. : A new sealant for knitted Dacron prostheses:
Minimally cross-linked gelatin. J. Vasc. Surg. 7: 414-419, 1988.

6) Stegmann, Th. A., Haverich, A. and Borst, H. G. : Clinical experience with a new collagencoated Dacron double-velour prosthesis. Thorac. Cardiovasc. Surg. 34: 54-56, 1986.

7）佐久間まこと，西部俊哉，垣野 匡ほか：新しい 人工血管の開発. 脈管学 32:209-214, 1992.

8）矢野 孝, 池澤輝男, 桜井垣久ほか：腹部大動脈 におけるアルブミンコート・人口血管の有用性. 脈管学 33: 121-127, 1993.

9）牧 真一，橋本明政，平山統一ほか：高純度コラ ーゲン被覆人工血管の臨床使用例の検討. 人工臓 器 21 : 1295-1298, 1992.

10）安達秀雄, 井野隆史, 井手博文ほか：プレクロッ ティング不要なゼラチン処理人工血管による上 行・弓部大動脈置換術. 胸部外科 $46: 586-589$, 1993.

11）土田弘毅，橋本明政，大越隆文ほか：ゼラチン被 覆人工血管の臨床使用例の検討。人工藏器 19 : 1444-1448, 1990.

12) Drury, J. K., Asthon, T. R., Cunningham, J. D., et al.: Experimental and clinical experience with a gelatin impregnated Dacron prosthesis. Ann. Vasc. Surg. 1: 542-547, 1987.

13) Sottiurai, V.S., Sue, S. L., Rau, D. J., et al.: Comparative analysis of pseudointim a biogenesis in Gelseal coated Dacron knitted graft versus crimped and noncrimped graft. J. Cardiovasc. Surg. 30 : 902-909, 1989.

14) Vohra, R., Drury, J. K., Shapiro, D., et al. : Sealed versus unsealed knitted Dacron prostheses: A comparison of the acute phase protein response. Ann. Vasc. Surg. 1: 548-551, 1987.

15) Reid, D. B. and Pollock, J. G. : A prospective study of 100 gelatin-sealed aortic grafts. Ann. Vasc. Surg. 5 : 320-324, 1991.

16) Barber, G., Bouchard, A., Cole, C. W., et al. : Immunologic response to collagen-impregnated vascular grafts: A randomized prospective study. J. Vasc. Surg. 12: 741-746, 1990.

17) Balzer, K., Werner, H. H., Adamek, L., et al. : Results after implantation of gelatinimpregnated bifurcated grafts. Thorac. Cardiovasc. Surg. 36 : 351-355, 1988.

18) Anderson, J. S., Price, T. M., Hanson, S. R. et al. : In vitro endothelialization of small-caliber vascular grafts. Surgery 101 : 577-586, 1987.

19) Nunn, D. B., Carter, M. M., Donohue, M. T., et al.: Prospective dilation of knitted Dacron aortic bifurcation graft. J. Vasc. Surg. 12: 291297, 1990. 